\title{
ADALÉKOK A TURIZMUS ÉS A MIGRÁCIÓ KAPCSOLATÁNAK ELMÉLETI MEGKÖZELÍTÉSÉHEZ ${ }^{1}$
}

\author{
(Contributions to the Theoretical Approach of the Relationship \\ between Tourism and Migration) \\ MICHALKÓ GÁBOR - ILLÉS SÁNDOR - \\ BERÉNYI ISTVÁN
}

Kulcsszavak:

Turizmus migráció szabadidō-magatartás

A turizmus és a migráció között meglévö kapcsolatok nyilvánvalósága ellenére azok tudományos igényü feltárásának viszonylagos háttérbe szorulása arra vezethetỏ vissza, hogy a két jelenség átfedéseinek és különbségeinek elméleti lehatárolása számos nehézség elé állítja a kutatókat. A tanulmány elsösorban a turizmus és a migráció bonyolult kapcsolatának gyermekcipöben járó kutatása során született nemzetközi és hazai szakirodalom feldolgozására épitve próbálja meg azokat az irányvonalakat kijelölni, amelyek mentén a jövöbeli magyarországi kutatások lefolytathatók.

\section{Bevezetö}

A területi mobilitás folyamatának egyik igen fontos eleme a térbeli mozgásként értelmezhető vándorlás. A jelenség bizonyos fázisai, a kiváltó okok és a folyamatok hatásaként kibontakozó következmények összehasonlíthatóak korunk egyik legjövedelmezőbb, az önfejlödése szempontjából komoly tartalékokkal rendelkezö „iparágával”, a turizmussal. Amíg a migrációt elsősorban az életkörülményekben bekövetkező javulás reménye, a turizmust a környezetváltozással együtt járó élményszerzés motiválja (Illés 2000; Michalkó 2002). A turizmus és a migráció között meglévö kapcsolatok nyilvánvalósága ellenére azok tudományos igényü feltárásának viszonylagos háttérbe szorulása arra vezethetó vissza, hogy a két jelenség átfedéseinek és különbségeinek elméleti lehatárolása számos nehézség elé állítja a kutatókat. A globalizálódás folyamatainak felerősödésével mind a turizmus, mind a migráció oly mértékben összetett jelenséggé vált, hogy a közöttük lévő összefüggések megértéséhez elengedhetetlen a holisztikus szemlélettel történő tanulmányozásuk. A transzdiszciplináris kutatás igényének szem elött tartása mellett fontos szerepe van a vizsgálandó probléma megközelítésének, a hangsúlyok elhelyezésének, mivel a turizmus szempontjából elsősorban az a kérdés, hogy a migrációban résztvevők magatartása értelmezhető-e turisztikailag, míg a migrációt kutató demográfusok a turisztikai élmény szerepének elvándorlásra gyakorolt motivációit kívánják tisztázni.

A turizmus és a migráció problematikájának vizsgálatára a magyarországi tudományos mühelyekben eddig csak érintőlegesen (gyakran a felvetés szintjén) került 
Michalkó Gábor - Illés Sándor - Berényi István :

Adalékok a turizmus és a migráció kapcsolatának elméleti megközelítéséhez.

Tér és Társadalom 17. évf. 2003/4. 51-65. p.

sor, miközben a hazánk földrajzi fekvéséböl és történelmi örökségéből fakadó geopolitikai viszonyok és a meglévő (kihasználásra váró) természeti erőforrások elengedhetetlenné teszik a témával kapcsolatos kutatásokat. Magyarország egyrészt a Balkánt Nyugat-Európával összekötő tranzitforgalom egyik fontos útvonala, a délszláv államok révén közel fekszik egy potenciális konfliktuszónához, másrészt Románia és Ukrajna révén olyan államokkal határos, amelyek lakosságának életszínvonala predesztinálja a vándorlási folyamatokat, így elkerülhetetlen a legális, vagy illegális migrációban való érintettsége. A trianoni döntés következményeként továbbra is figyelembe kell venni a határon túli magyarság betelepülésének szándékát, amelyet az itt élő rokonoknál, ismerősöknél tartott turisztikai célú látogatások is inspirálnak (Tóth 1997). Másik oldalról Magyarország vonzást gyakorol az Európai Unióból, vagy a tengerentúlról érkezö külföldiekre is, akik turistaútjaik során megismerkedtek hazánk vonzeröivel, és úgy dönthetnek, itt kívánnak letelepedni (Illés 2001). A turisztikai vonatkozású belföldi vándorlást a már említett munkaerö vonzás, a túlzott vendégforgalom miatti taszítás, vagy egy egykori hétvégi ház állandó lakhellyé történő átminősítése motiválhatja.

\section{Szimbiotikus csomópontok a turizmus és migráció kapcsolatában}

Ha elfogadjuk, hogy a turizmus egy olyan interszektorális jelenség, amelynek lényegi elemét az egyén élményszerzéssel és szolgáltatások igénybevételével együtt járó környezetváltozása képezi (Michalkó 2002), akkor a turizmus migrációval való összefüggéseinek feltárására, a két jelenség közös vizsgálati pontjainak bemutatására elsősorban a területi elem és az elmozdulás mentén kerülhet sor. A nemzetközi kutatói társadalomnak is csak a kilencvenes évek végére sikerült a turizmus és a migráció kapcsolatrendszerében addig feltárt ismereteket komplexen összegeznie. 1999-ben a Nemzetközi Földrajzi Unió fenntartható turizmus földrajzával foglalkozó munkacsoportja (IGU Study Group on the Geography of Sustainable Tourism) elindított egy projektet, amellyel az addig létrejött kutatási eredmények elméleti

szintézisét kívánták megteremteni. ${ }^{2}$ A vizsgálatban részt vevő szakemberek rámutattak, hogy a mobilitás új formáinak megjelenése és a szabadidős tér átalakulása a világ tőkefelhalmozási folyamatának természetében bekövetkezö változások válaszlépéseiként tételezhetők fel. A turizmus és migráció kapcsolatát elsősorban két alapvető aspektusból vizsgálták, a termelés és a fogyasztás oldaláról. Mind a termelés, mind a fogyasztás vezérelte idegenforgalmi migráció szoros kapcsolatot mutat a hagyományos migrációs modellekkel, amelyekben a helykeresés és a döntéshozatal meghatározó szerepet játszik (Rédei 2001).

A kereslet turistaiparral szemben megnövekedett mennyiségi és minőségi elvárásainak kielégítését, vagyis a termelést (szolgáltatások biztosítását) szolgáló migráció a turisztikai munkaeröpiacon létrejövő ür kitöltését biztosítja. A világ turisztikailag frekventált területein, ahol jelentös szerepe van az ún. $4 \mathrm{~S}$ (sun, sand, sea, sex), a napfényre, a homokos tengerpartra, a vízre és a laza erkölcsi életmódra alapozódó 
Michalkó Gábor - Illés Sándor - Berényi István :

Adalékok a turizmus és a migráció kapcsolatának elméleti megközelítéséhez.

Tér és Társadalom 17. évf. 2003/4. 51-65. p.

vonzerőknek és az ezeket fogyasztó tömegturisták jelenlétének, ott egyre széleskörủbb szolgáltatásokat igényel a turisták kereslete. Mivel a helyi és környékbeli munkaerő már nem képes kiszolgálni a növekvő vásárlóerő támasztotta igényeket, ezért külső munkaerö bevonására van szükség. A turizmus munkaerőpiacán alkalmazandó migránsok iránti igény leginkább az alacsonyabb képzettséggel is betölthető munkahelyek oldaláról jelentkezik. Az idegen országból érkező dolgozókat elsősorban a vendéglátás és az ún. kollektív szolgáltatások (vízijármüvek, sporteszközök kölcsönzése, takarítás) területén alkalmazzák. Ezeken a posztokon nagy számban munkába állított, alacsony fizetési igényủ migráns jelentős előnyöket hozhat a munkaadójának az üdülöhelyek egymás közötti versenyében. A termelésorientált idegenforgalmi migrációban részt vevő munkaerő másik alkalmazási területének a magasabb képzettségi szintet igénylö menedzseri beosztások tekinthetők, mely státuszok betöltéséhez az adott térségben nem áll rendelkezésre az elvárt normáknak megfelelö szakember, így alkalmazásuk általában a nemzetközi láncokon belüli munkaerőtranszfer következménye.

A turizmussal leginkább a fogyasztásorientált migrációs folyamatok állnak szimbiózisban, amelyek a turisztikai tér használatának gyakorlatától függöen a migráció motivációjával, a tartózkođás időtartamával és a szállásként igénybevett ingatlanhoz való viszonyulással írhatók le. A fogyasztás vezérelte idegenforgalmi migráció tipikus példájának tekinthetö egyrészröl a korábban megvásárolt ingatlan (második otthon) használatával kombinált utazás, mely esetekben a vakáció hossza jelentősen meghaladja az üdülöturizmusban szokásos időtartamot, így a migránsok a tradicionális üdülökhöz képest szorosabb kapcsolatot tudnak kiépíteni az állandó lakossággal. Másrészről e folyamat táplálja a nyugdíjas migránsok fokozódó részvételét az idegenforgalmi értékekkel bíró területeken. Az IGU említett projektjében részt vevő kutatók arra is felhívták a figyelmet, hogy léteznek olyan ismert turisztikai terïletek, amelyekre irányuló migráció csak közvetetten hozható összefüggésbe a turizmussal, mert nem az ott betöltendő idegenforgalmi munkahelyek vagy az ígéretes befektetéssel kecsegtető ingatlanvásárlás, hanem az idegenforgalmi bevételekből származó kedvezőbb életkörülmények, vagy a vendégforgalom kiszolgálását hivatott közlekedési infrastruktúra jelent motivációt.

A turizmus és a migráció kérdésének együttes elemzését különös módon ösztönzi, hogy az utóbbi évtizedben maga a turizmus is jelentős átalakulásokon ment keresztül, ami elsösorban a termelés (szolgáltatások biztosítása) és a fogyasztás új megjelenési formáira vezethető vissza:

- A globalizációval párhuzamosan kiterjedt a turizmus piaca, amely a világ bármely pontján megkövetelte az idegenforgalmi munkaerő gyors és rugalmas áthelyeződését, illetve utánpótlását.

- A turizmus fejlesztését biztosító tőke nemzetköziesedése olyan, akár távoli országból érkezö menedzsereket igényelt, akiknek az alkalmazásával garantálható volt a befektetések megtérulése. 
Michalkó Gábor - Illés Sándor - Berényi István :

Adalékok a turizmus és a migráció kapcsolatának elméleti megközelítéséhez.

Tér és Társadalom 17. évf. 2003/4. 51-65. p.

54 Michalkó Gábor-Illés Sándor-Berényi István

TÉT XVII. évf. 2003

- A világgazdaságban realizálódó bevételek eloszlásában végbemenő területi változások hozzájárultak a mobilitás erősödéséhez.

- Korszerüsödött a mobilitás biztosításában közremủködő közlekedési infrastruktúra.

- A kommunikációs technológiaváltás felgyorsulása lehetővé tette az információ és a kulturális minták gyorsabb áramlását.

- A turisztikai tevékenységekben való fokozatos társadalmi részvétel kiszélesedését segítette elỏ a munkával töltött évtizedek után, a nyugdíjas évek alatt jelentkező szabadidős igény, amit a demográfiai, egészségügyi tényezők is erősítettek.

- A munka és a szabadidő viszonylatában észlelhetó érték-transzformáció háttérbe szorítja a vagyonokban manifesztálódó tárgyi valóság elsődlegességét. A társadalmi megítélésbeli változás nagyobb hangsúlyt biztosít a nem tárgyi viszonyok (különösen a jövedelmek szabadidős tevékenységekre fordított felhasználásának) értékként történő elismerésének.

A turizmus és migráció kapcsolatával foglalkozó kutatók többsége hangsúlyozza, hogy annak ellenére, hogy a mobilitás egyike a kortárs földrajz központi kutatási területeinek, a két jelenség közötti összefüggések vizsgálata mindeddig elhanyagolt problematikának számított. Hozzáfüzik, hogy a turizmus és a migráció között meglévỏ különbségek lehatárolásának nehézségei is hozzájárultak ehhez (WilliamsHall 2000). Alapvető hasonlóságként említhető, hogy a szakirodalomban mindkét jelenség definíciója vita tárgyát képezi. A migrációt általában olyan mozgásként írják le, amely egy területi egység átlépésével jár együtt, ugyanakkor egyfajta állandóságot (az időben hosszabb tartózkodás [letelepedés] szủkségességét) is hordoz magában. A mozgást legtöbbször a határ két oldalán meglévő fejlettségbeli különbségek váltják $\mathrm{ki}$, amely eltérések a határ nélküli világ szükségessége, vagy a globalizáció uniformizáló hatása hangoztatásának ellenére is fennállnak. A határoknak föleg a belépés korlátozásában van szerepük, mert ahonnan eljönnének, onnan kiengedik az embereket, de ahova menni akarnak, ott szigorú szabályokkal kell szembenézniük. Az elméleti problémák között szerepel a vándorlás állandóságának kérdése is. Bell és Ward (2000) a turizmus és migráció kapcsán az előbbi átmenetiségének, az utóbbi állandóságának hangsúlyozása mellett tesz a mozgás időtartamára vonatkozó teoretikus megállapításokat. Az állandó migráció az év bármely időszakában elöfordulhat, az átmeneti jelleggel bíró turizmus azonban (szinte szükségszerủen) szezonális csúcs- és mélypontokat von maga után. Amíg az állandó migrációval kapcsolatban többé-kevésbé megfelelő fogalmaink vannak, addig az átmeneti tartózkodást tekintve kevesebb fogódzó áll a kutatók rendelkezésére. Sok olyan mozgás létezik, amelyik nem szerepel a konvencionális migrációs mérésekben, nem illeszkedik tisztán a tér-idő grafikon metszete által létrehozott sémába, de fogalmilag hasonlóak az átmeneti mozgásokhoz (1. táblázat). 
Michalkó Gábor - Illés Sándor - Berényi István :

Adalékok a turizmus és a migráció kapcsolatának elméleti megközelítéséhez.

Tér és Társadalom 17. évf. 2003/4. 51-65. p.

TÉT XVII. évf. 2003 『 4

Adalékok a turizmus és a ...

1. TÁBLÁZAT

Az állandó és az idöszakos mobilitás tipológiája

(Typology of Permanent and Periodical Mobility)

\begin{tabular}{|c|c|c|}
\hline \multirow[b]{2}{*}{ A tartózkodás idötartama } & \multicolumn{2}{|c|}{ A mobilitás motivációja } \\
\hline & $\begin{array}{l}\text { Termeléssel } \\
\text { kapcsolatos }\end{array}$ & $\begin{array}{c}\text { Fogyasztással } \\
\text { kapcsolatos }\end{array}$ \\
\hline Állandó áthelyezödés & Munkavégzés & $\begin{array}{l}\text { Ingatlanvásárlás } \\
\text { Szórakozási, müvelődési } \\
\text { lehetőségek orientálta } \\
\text { migráció }\end{array}$ \\
\hline $\begin{array}{l}\text { Ideiglenes } \\
\text { (legalább egy éjszakás } \\
\text { tartózkodás) }\end{array}$ & $\begin{array}{l}\text { Üzleti utazás } \\
\text { A lakóhelytől távolabbra } \\
\text { történö ingázás } \\
\text { Szezonális munkavégzés }\end{array}$ & $\begin{array}{l}\text { Családlátogatások } \\
\text { Kirándulások } \\
\text { Vakációk } \\
\text { Szezonális migráció } \\
\text { Hosszabb időtartamú utak } \\
\text { Konferenciák és ülésezések } \\
\text { Tanulmányi kurzusok } \\
\text { Kórházi ápolás } \\
\text { Bebörtönzés }\end{array}$ \\
\hline Mindennapi mozgás & Ingázás & $\begin{array}{l}\text { Vásárlás } \\
\text { Rekreáció }\end{array}$ \\
\hline
\end{tabular}

Forrás: Bell-Ward (2000).

A turizmus és migráció közös eredője a ,jó helyek" keresésében rejlik, ami gyakran a korábbi utazásokból fakadó tapasztalatokra alapozódik. E mellett nem szabad megfeledkezni arról sem, hogy a migrációban résztvevők meglévö idegenforgalmi hálózatokat (közlekedés, szállás, vendéglátás) használnak. Léteznek azonban ún. migráns hálózatok is, amelyek interperszonális kapcsolatok (rokonok, ismerősök, barátok) láncolatát alkotják, ezek fokozzák a mozgás valószínüségét, csökkentik a költözködés költségét és kockázatát, növelik a migráció várható nettó hozamát (Massey 2001). A migráció müködtetésére olyan informális intézmények (az embercsempészettől a névházasságon keresztül a kölcsönt biztosítókig) alakultak, amelyek sajátos szolgáltatásokat nyújtanak a rászorulóknak. Az idegenforgalom és a migráció összefüggéseinek vizsgálata jelentős mértékben elősegíti a két jelenség önmagában való megértését, ugyanakkor rámutat értelmezésük egyes hiányosságaira is. Zolberg (2001) szorgalmazza, hogy a migrációelmélet teoretikus vonásait és hangsúlyait a változó társadalmi realitások fényében szükséges módosítani. A migráció ortodox megközelítésén (taszítás-vonzás, kereslet-kínálat) túl kell lépni, mert a folyamat nem elkülönült nemzetállamok közötti légüres térben játszódik, hanem egy történelmileg kialakult, átfogó világrendszer keretein belül, mely folyamatnak a transznacionális vállalatoktól a háztartásokig sok-sok szereplöje van. A migráció a globális rendszer egyik belső folyamata, így a kutatásoknak egyre inkább a migráció és az egyéb nemzetközi folyamatok (mint amilyen a turizmus) közötti összefüg- 
Michalkó Gábor - Illés Sándor - Berényi István :

Adalékok a turizmus és a migráció kapcsolatának elméleti megközelítéséhez.

Tér és Társadalom 17. évf. 2003/4. 51-65. p.

gések vizsgálatára kell irányulniuk. Illés (2000) megállapítja, hogy a migráció hasonlóképpen a turizmushoz - akkor került a vizsgálatok központjába, amikor az kezdett tömeges méreteket ölteni. Felhívja a figyelmet arra, hogy a változó világban a migráció fogalma, a turizmuséhoz hasonlóan felhígult. Mindkettőben alapvetỏ a mozgás, a térbeli mobilitás, a népesség helyváltoztató mozgása. Ha vándorláson a népesség adminisztratív határt átlépő lakóhely-változtatását értjük, akkor nincsenek könnyü helyzetben azok a kutatók, akik a jelenséget a turizmustól akarják megkülönböztetni. Akár a nemzetközi turizmust, akár a nemzetközi migrációt vizsgáljuk fontos - bár egyre nehezebben kutatható - szerepe van a határoknak, amelyeket a modellek többsége szerint a résztvevőknek át kell lépniük. A nemzetközi határok mobilitást gátló szerepe folyamatosan csökken, mint ahogy az a funkcionális távolság is, ami sok utazót elrettentett a szomszédos ország felkeresésétöl (Timothy 1995). A turizmuskutatók is vizsgálják az elmozdulás (elindulás) helyét, mivel ennek szociokulturális viszonyai meghatározzák a célállomáson tanúsított turisztikai magatartást. Ha megvizsgáljuk a migráció klasszikus osztályozását, az elkülönítési kritériumokat és az azokhoz tartozó jellegzetes típusokat, akkor valóban több hasonlóságot vélünk felfedezni a migráció és a turizmus kapcsolatában. A migráció kutatása szétaprózódott, az elszigetelt területek között ritka a kommunikáció, ez az állítás a hazai turizmuskutatás viszonyaiban is helytálló (Michalkó 2002). A migráció folyamatában a tér és idődimenziónak össze kell kapcsolódnia, csak egy bizonyos idő után beszélhetünk vándorlásról, a turizmusban ez a tényező kevésbé dominál, mivel a bevásárlóturizmus kimondottan rövid idötartamra terjed ki. A migráció osztályozása során külső és belső vándorlásról, hasonlóképpen belföldi és nemzetközi turizmusról beszélünk. Önkéntes és kényszervándorlást említünk, míg a turizmus is lehet egyfajta kényszer, amikor a taszító erők kizárólagossága áll fenn, vagyis az élet megmentését szolgálja az utazás (turistaútnak álcázott disszidálás). Megkülönböztetünk egyéni és csoportos vándorlást (ez a turizmusra is vonatkoztatható: egyénileg és csoportosan szervezett utak), igaz, a vizsgálat tárgya mindig az egyén. A migrációkutatók azért vizsgálják a döntéshozatali mechanizmust, mivel az egyén, vagy a család életstratégiájáról kell dönteni, amelyben komoly szerepe van az indítéknak, ezt a turizmuskutatók a szabadidő eltölttés helyének kiválasztása kapcsán, illetve a motivációk lehatárolása során veszik górcső alá.

\section{Turizmus és munkaeröáramlás}

A turizmus jelentősen kihat a munkaerö-áramlásra, mivel ahol kevés a turizmusban alkalmazható, vagy elhelyezkedni vágyó munkavállaló, illetve a helyi munkaerö számára nem megfelelőek a kínált bérek, ott elöbb-utóbb megjelenik az idegen munkaerö. Ez a folyamat napjainkban különösen a fejlödỏ országokban érvényesül, ahol elsősorban a szállodák és vendéglátóhelyek élére gyakran külföldröl jön a munkaerö (Williams-Hall 2000). Ugyanakkor a globális városokban, ahol erös gazdaság és magasan képzett munkaerö koncentrálódik, jelentős kereslet alakul ki a 
Michalkó Gábor - Illés Sándor - Berényi István :

Adalékok a turizmus és a migráció kapcsolatának elméleti megközelítéséhez.

Tér és Társadalom 17. évf. 2003/4. 51-65. p.

kevésbé képzett idegenforgalmi munkaerỏ (pincér, londiner) iránt (Massey 2001). A turizmus vonzerői az adott helyszínen viszonylag állandónak mondhatók, szemben a munkaerö iránti igénnyel, ami a kereslet függvényében változhat. Azokban a térségekben, ahol a tömegturizmus visszaszorulóban van, és inkább az egyéni úti célok jelennek meg, erősödik a térbeli szétszóródás, ezzel párhuzamosan a nemzetközi munkaerőszükséglet csökken, a helyi munkaerô teret nyer. A kormányok a külföldi munkaerő kiszorítása érdekében úgy reagálhatnak, hogy erősítik a szakmai képzést, intézkedéseikkel a hazai munkavállalók megbecsülését célozzák.

A termelésorientált migráció vizsgálatával kapcsolatban Aitken és Hall (2000) megállapítják, hogy a nemzetközi migráció modelljei bizonyíthatóan kapcsolatban vannak a technológia és az információ áramlásával. A bevándorlók magukkal hozzák saját szellemi tỏkéjüket, ami a szakértelemben, a gyakorlati tudásban és a marketing formájában manifesztálódik. A munkatapasztalat, a vállalkozói szellem, a tőke és az üzleti hálózat mind-mind a bevándorlók pozitív velejárója. A bevándorlók kapcsolatai hatással vannak az anyaországuk exportjára, fellendítik a tartózkodási helyük behozatalát, melynek során előnyben részesítik saját országuk áruit. $\mathrm{A}$ bevándorlók a kiskereskedelemben is hasznos szerepet jâtszanak, ismerik a célterület nyelvét és kultúráját, ami elősegíti az áruk hétköznapi értékesítését, de az export-szolgáltatásokra - mint amilyen a turizmus - is hatással vannak. A bevándorlók alkalmazása sokkal fontosabb a szolgáltatóiparban, mint a többi iparágban. A turizmusban elsődleges a kultúrákon átívelő szaktudás. A szerzőpáros Új-Zélandon végzett vizsgálatának eredménye megállapította, hogy a külföldi szakértelem - ha nem is döntő mértékben - közrejátszik a vállalkozások sikerében. A megkérdezettek a külföldi munkavállalók konkrét szerepéröl a következőket mondták: a külföldiek tudása a szolgáltatás értékesítésében játszott közre, a nyelvtudás az információs központoknál meghatározó szerepű, a kommunikációs készség pedig minden szektorban fontos.

Bianchi (2000) az üdülőmunkások (az üdülövendégeket turista jogviszonyban kiszolgáló munkavállalók) oldaláról közelít. Ezek a fajta munkavállalók klasszikus értelemben sem nem turisták, sem nem munkások. Valahol a korábbi, nomadizmussal foglalkozó tanulmányok kategóriái (a csavargó, a hajléktalan, a száműzött, az emigráns, az újkori utazó, a vándorcigányok, a zarándokok, a diaszpórában élők) között kell öket elhelyezni. Az újdonság „csupán” annyi, hogy választott életformájuk a saját életútjukon belül, igen nagy valószínüséggel átmenetinek tekinthetỏ. A nomadizmus a fizikai, az intellektuális és a szexuális szabadság metaforája, amelyben a munka egyesül a turisztikai tapasztalattal. A turizmus és a munkaorientált migráció közötti határok azonban nem átjárhatatlanok. A turizmussal kapcsolatos munkaerőmigráció szoros kapcsolatban van a turizmus mediterrán tengerparton észlelhető polarizációjával. Ez különösen Spanyolország belső falusi területeiröl a costa brava-i üdülök felé zajló migrációban volt észlelhetö. A Hawaii szigeteken tartózkodó, ott munkát vállaló amerikai középosztály alternatív életstílusnak tekinti a szabadidős tapasztalatokat. A migráció és a turizmus kapcsolatát 
Michalkó Gábor - Illés Sándor - Berényi István :

Adalékok a turizmus és a migráció kapcsolatának elméleti megközelítéséhez.

Tér és Társadalom 17. évf. 2003/4. 51-65. p.

nem lehet megérteni a posztindusztriális társadalmak átalakulásának megértése nélkül. A vizsgálatok során abból kell kiindulni, hogy a posztindusztriális világban a munka és a szabadidő közötti kapcsolatok elmosódnak. Az üdülömunkások társadalmi jellemzői kevésbé karakterisztikusak, egyaránt átfogják az új kőzéposztálybeli, valamint az alacsonyabb iskolázottságú marginális csoportokat. Európa üdülömunkásainak to̊bbsége EU országbeli, mert ők szabadon utazhatnak, de szívesen fogadják az USA-ból és Ausztráliából érkezőket is. A valóságban a szegényebb északiak mennek délre. Olyan diplomások is megjelennek a turista munkások között, akik nem kívánnak belépni a helyi formális és keményen szabályozott munkaerőpiacra. A turistaként végzett munka társadalmi tapasztalást jelent, egy kísérlet, hogy erósítsék kapcsolataikat a helyi társadalommal. A munka számos északi számára kulturális kitekintésként értelmezhető, kủlönösen a Nagy-Britanniából, Németországból, a Benelux államokból, Skandináviából érkezőknek, akiknek a Mediter-ránum rutinszerü menekülési útvonallá vált a nedves klímából, a stresszes munkahelyekről, a környezetszennyezéssel sújtott ipari térségekbỏl. Az üdülőenklávék és a turista jachtkikötők társadalmi, gazdasági csomópontokat alkotnak, amelyek köré a turistamunkások gyülekeznek. A nemzetközi munkaerőmigráció mértéke mind a turizmusban, mind a vendéglátóiparban nehezen szabályozható. Ahol a helyi munkaerő alacsonyan képzett, vagy a munkavállalás keretfeltételeinek betartása nehezen megoldható, ott a képzési és kulturális töke, aminek az északiak birtokában vannak, kedvezőbb helyzetbe hozzák öket a turizmus munkaeröpiacán. A helyi munkaerő szociális biztonságra, bejelentett munkahelyre vágyik, míg az északról érkezők számára ezek átmenetileg elhanyagolható tényezỏk, így olcsóbban tudják a munkát elvállalni.

A turizmusban alkalmazott külföldiek számtalan esetben konfliktusforrást jelentenek a helyi munkaerópiacon, e mellett láthatatlan vonalakat húznak faji-etnikai alapon, vagy a legális-illegális munkavállalás mentén, amivel közvetetten elősegíthetik a tóke felhalmozódását az idegenforgalomban (Williams-Hall 2000). A migráció köztudottan enyhíti a munkaeröhiányt, az alacsony bérért dolgozó külföldiek révén a fizetések nem gerjesztik az inflációt, a helyiek bérigénye leszorítható. Az idegenforgalmi munkaerő áramlása nemek szerint is differenciálódik, vannak tipikus női és férfi munkakörök a turizmusban. A nők munkavállalásuk során két akadállyal is találkozhatnak, egyik a nemi, a másik a bevándorlói státusukból fakad. Bianchi (2000) is kiemeli, hogy ami az üdülőmunkások többségét összekapcsolja, az a velük szembeni gyanakvás, az ellenséges érzület, amit a helyi lakosság tanúsít feléjuik. Felhívja a figyelmet, hogy miközben egyre kiterjedtebbé válik a globalizáció jelensége, addig a vándorlás egyre erősebb megszorításokkal bír. Akik a fejlett világhoz képest kívüllről érkeznek, szigorításokkal találják szembe magukat, de a már említett nemi és etnikai diszkriminációval is szembe kell nézniưk.

A munkaerőáramlás témájához szorosan kapcsolódnak a külfỏldi országban folytatott tanulmányok is. A világban a tanulási célú migráció a nemzetközi mozgás jelentỏs és egyre növekvő szeletét adja (Rédei 2002). A diákok képzési célú mobilitása során a potenciális humántỏke áthelyeződik egy másik országba, ahol gyarapo- 
Michalkó Gábor - Illés Sándor - Berényi István :

Adalékok a turizmus és a migráció kapcsolatának elméleti megközelítéséhez.

Tér és Társadalom 17. évf. 2003/4. 51-65. p.

dáshoz vezet, ahonnan eláramlik, ott pedig veszteségeket okoz. Az egész életen át folyó tanulás (longlife learning) terjedő szemlélete tovább erösíti a tanulással összefüggő, hosszabb utazásokat, melyek regisztrálása a nyugdíjas migrációhoz hasonlóan nehézkes.

\section{A nyugdíjas migráció idegenforgalmi vetületei}

A turizmus és migráció kapcsolatának egyik eklatáns példája a nyugdíjas korú népesség aktív életszakasza utáni lakóhelyváltoztatása. A nyugdíjas migráció életstílus-orientált, résztvevői sokszor elöidézöivé válnak a dezurbanizációs folyamatoknak. A szakirodalomban többféle kategorizálás létezik, mindegyikben közös, hogy megmutatkozik bennük a nyugdíjas korú migráció bonyolultsága és más látogatóktól, migránsoktól való megkülönböztetése (Williams-Hall 2000). A nyugdíjas korú migráció okait az öregedő népesség számának bỏvülésében, a meghosszabbodott és egyre aktívabbá váló idős kor kiteljesedésében, a változó nyugdíjas mintákban, a növekvő jövedelmekben, a munkával és a szabadidővel kapcsolatos bővülö ismeretekben kell keresni. A nyugdíjas migráció 3 fő motivációja: a család újraegyesítése, visszatérés a szülőföldre, szabadidős helyek felkutatása. Truly (2002) az amerikai nyugdíjasok Mexikóba történő migrációjának bemutatása kapcsán megállapítja, hogy a nemzetközi nyugdíjas migráció dinamikus területét képviseli a kutatásoknak. Véleménye szerint a turizmus sokkal inkább idöszakos, mint maga a nyugdíjas migráció. Az USA nyugdíjasainak $21 \%$-a migráns, és ez az arány növekedni fog, amikor nyugdíjba vonul a „BabyBoom” nemzedék. Állítása szerint a korábbi utazások kulcsszerepet játszanak a nyugdíjas migrációs döntésekben. A migrációban leginkább Lee modellje érvényesül, a tér elönyei vonzó hatások lehetnek, míg a személyes tragédia, vagy bármely társadalmi, kulturális, vagy gazdasági ok taszítást eredményezhet. Williams-King-Warnes-Patterson (2000) a téma vizsgálata kapcsán arra jutottak, hogy a nemzetközi nyugdíjas migrációra az egész életen át tartó karrier utazások mellett számos tényezó is hat: egyre inkább elmosódnak a határok otthon és nyaraló, munka és szabadidő között, az utazási döntéseknél elötérbe kerül a rokonok és barátok meglátogatásának szükségessége is. Négy dél-európai ország (Olaszország, Málta, Spanyolország, Portugália) egy-egy régiójában élö, összesen 825 brit nyugdíjas között végzett felmérés alapján megállapítják, hogy a nyugdíjas migrációban résztvevők mielött megtették, már évekkel megelózöen gondolkodtak a költözésen, így ez nem egy egyszerü, hirtelen elhatározott költözés, hanem egy hosszú, döntési-mérlegelési folyamat eredménye. Feltételezték, hogy egy kétlépcsős folyamatról van szó, amelyben első maga a migrációs döntés, a második a célállomás kiválasztása. A megkérdezettek egyik fele valóban azt mondta, hogy több alternatívából is választhatott, a másik pedig azt, hogy csak egyből, tehát nehezen bizonyítható az egylépcsős (az utazás tényének és célállomásának együttes kiválasztása) vagy a kétlépcsös modell kizárólagossága. 
Michalkó Gábor - Illés Sándor - Berényi István :

Adalékok a turizmus és a migráció kapcsolatának elméleti megközelítéséhez.

Tér és Társadalom 17. évf. 2003/4. 51-65. p.

\section{TÁBLÁZAT}

A nyugdijas célterületek választásának legfontosabb motívumai a Mediterránumban (\%)

(The Most Important Motivations of Pensioner's Objectives in the Mediterranean)

\begin{tabular}{lcccc}
\hline & Nyaralás & Munka & Család & Összes \\
\hline Toscana & 47,8 & 23,3 & 28,9 & 100 \\
Málta & 51,9 & 19 & 29,1 & 100 \\
Costa del Sol & 87,3 & 4,7 & 8 & 100 \\
Algarve & 86,8 & 7,4 & 5,8 & 100 \\
Összes & 72,5 & 11,5 & 15,9 & 100 \\
\hline
\end{tabular}

Forrás: Williams et al (2000).

A ,jó" helyet kereső migránsok nem költöznek olyan környezetbe, amelyet azelött nem látogattak rendszeresen, sőt a korábbi szabadságokat a döntés legfontosabb forrásaként értelmezik (2. táblázat), de vannak olyan kutatók, akik vitatják, hogy az érintettek a mentális térképükben keresnék a költözés célterületét. Nincs tehát teljes konszenzus a kutatók között a turisztikai élmény elsődlegességét tekintve sem. A turizmusból szerzett tapasztalatok nem egyforma mértékben befolyásolják a migrációs döntést. Egy nyaralás vagy egy rokonlátogatás nem ugyanazt a tapasztalatot jelenti, nem egyforma a megszerezhető információ mélysége. Az üdülések ugródeszkaként szolgálhatnak ebben a folyamatban egy nyaraló (második otthon) megvásárlásához. A döntés során fontos kapcsolatnak tekinthető a második otthon birtoklása, amely fokozatos átmenetet jelent a rövid nyaralás, a szezonális tartózkodás és az állandó letelepedés között.

\section{Turizmus és a határon átnyúló társadalmi kapcsolatok}

A baráti és rokoni kapcsolatok földrajzi bővülése ösztönzőleg hat a világban észlelhető migrációra. Az egyének eltérő életstratégiảjuk révén egyre távolabb kerülhetnek egymástól, a kapcsolattartás a turizmuson keresztül mégis megoldott. Feng és Page (2000) az ázsiaiak Új-Zélandra való migrációját tanulmányozva megállapítják, hogy a szigetcsoport kínai populációjának növekedésében a bevándorlás fontos szerepet játszik, így napjainkban a kínaiak a legnagyobb ázsiai kisebbséget képviselik az országban. Az etnicitás növekvő tényezöje a barát és rokonlátogatásokkal motivált turizmusnak. Az etnikai turizmus lényege, hogy a benne részt vevő külföldiek anyaországba való ideiglenes visszatérése vagy ideiglenes munkavállalása folyamatos letelepedés nélkül valósul meg. Az etnikai turizmus még akkor is hasznot hoz, ha a benne részt vevők nem szállnak meg kereskedelmi szálláshelyeken. A szerzőpáros Aucklandban végzett, 358 kérdöív eredményeit feldolgozó vizsgálata szerint a kínaiaknál a tradíciók és a családi értékek rendkívül fontosak (ez a vallásukra, a konfucianizmusra is visszavezethetö), így a bevándorló kínaiak 
Michalkó Gábor - Illés Sándor - Berényi István :

Adalékok a turizmus és a migráció kapcsolatának elméleti megközelítéséhez.

Tér és Társadalom 17. évf. 2003/4. 51-65. p.

utazásai a család által meghatározottak, amelyen belül a gyerekek is befolyással vannak az utazási döntésre. A kínaiak 62\%-a mindig családdal utazik, 80\%-uk utazása megszervezéséhez utazási irodát vesz igénybe, 79\%-uk Kínába hazatérve saját házában száll meg.

Beer (2000) vizsgálata a turizmus és a társadalmi kapcsolatok migrációs hatásainak sajátos elemére világít rá. Kutatása szerint sok házasság köttetik a fülöpszigeteki nők és az odalátogató, elsősorban német férfiak között. A kilencvenes években a rokoni hálózatok és a barátok voltak a német-fülöp-szigeteki házasságok fö közvetítői, a már Németországban élö, egykor fülöp-szigeti nök segítettek összehozni az otthon élök számára a kapcsolatokat. Elöször a férfinak kellett a szigetekre utazni, mert a turistavízumot a nők számára nagyon nehezen lehetett megszerezni. A német férfi gyakran már kiutazásakor tudja, hogy ott oltár elé vezeti a kiválasztott nőt. Az utazás fó motivációja, hogy a fülöp-szigeteki nők köztudomásúan ideális feleségekké válnak, amire az útikönyvek is felhívják a figyelmet, de ügynökségek is dolgoznak erre a piacra, házassági szafarik, vagy újságban meghirdetett ajánlatok révén. A Fülöp-szigeteken rituális szertartással rendezik az álomesküvőtt, és Németországban anyakönyveznek. A német férfi rokonai, barátai már az esküvőn megismerkedhetnek a fülöp-szigeteki nőkkel, unokahúgokkal, ami tovább gerjeszti a „házasságturizmust”. A szigeteken a prostitúció erös kulturális aspektust kap, a kapcsolatokat sokkal inkább a müvészet (hospitally girls, cultural dancer), mint a sex hatja át. Itt a sex-turizmus házasságturizmussá fejlődött. Az otthon élöknek a külföldi rokoni hálózatok igen fontos gazdasági eröforrást jelentenek.

Szabó (2002) a gyermekmigrációval kapcsolatos ismeretek elemzésekor tár fel olyan tényezöket, amelyek átvezethetnek a turizmus témakörébe. A gyermekek sajátos motivációját jelentik a migrációs utazásoknak. A külföldön jövedelemszerző tevékenységet folytató aktív személyek vagy hazautaznak a gyermekeikhez, vagy a gyermekeket hozatják ki magukhoz. A második esetben a gyermek egyértelmủen turistává válik. A gyermekek akár kedvezményezettek, akár áldozatok, a legtöbbször passzív résztvevöi a folyamatoknak, azonban szocializálódásukhoz hozzátartozik az utazás, így felnőve nagyobb eséllyel válhatnak valódi turistává.

Az aktív életszakaszban bekövetkezö, jobbára külső tényező hatására történő kivándorlás, az emigráció is számos idegenforgalmi vonatkozást hordoz magában. Kezdetben a fejletlen közlekedési eszközök miatt az emigráció egyirányú volt, az Atlanti-óceánt jobbára csak egyszer szelték át, ma turistaként gyakran hazalátogatnak a tengerentúlról, ami újabb mozgást idézhet elö, de könnyebben visszatérhetnek a szülöföldre a nyugdíjazás, a siker, vagy a kudarc miatt is, persze megtakarított pénz, és leginkább a humán tőkének nevezhetö nyelvtudás birtokában (Williams-Hall 2000). Akik visszajönnek, nyelvtudásuk birtokában elhelyezkedhetnek az idegenforgalomban, vagy vállalkozók lehetnek, mert annyi pénzt tudnak megtakarítani, amennyi egy kis- vagy középvállalkozáshoz elegendő, de elöfordul, hogy csak házat vesznek és kiadják a turistáknak. 
Michalkó Gábor - Illés Sándor - Berényi István :

Adalékok a turizmus és a migráció kapcsolatának elméleti megközelítéséhez.

Tér és Társadalom 17. évf. 2003/4. 51-65. p.

Cluzeau (2001) is rámutat arra, hogy Korzika, Spanyolország, Madagaszkár történelme kitermelt olyan diaszpóra csoportokat, akik kénytelenek voltak elmenekülni szülőföldjükről vagy saját maguk elhatározásából máshol telepedtek le. A turizmusban is komoly szerepet játszik a diaszpórák jelenléte. Vannak, akik ezt etnoturizmusnak vagy közösségi turizmusnak nevezik. A turizmus olyan társadalmi tényező, amely újraéleszti, szorosabbra füzi a diaszpórában élők meglazult kapcsolatait az anyaországgal. Az emigránsok hosszabb időtartamra hazatérve nem vesznek szálláshely-szolgáltatást igénybe, inkább ingatlant vásárolnak maguknak, így ingatlanügynökök dolgoznak az emigrációban élök keresletének felkeltésére. 2000-ben a Marokkóban megfordult 4,37 millió turistából közel 1,65 millió volt a külföldön élỏ marokkói. A diaszpóra azzal, hogy aktívabban védi az eredeti környezetet, ahol felnőtt, gátolhatja is a turizmus fejlődését, például Bretagne-ban a hazatérő bretonok felvásárolják az ingatlanokat, és nem járulnak hozzá a fejlesztésekhez. A háborúk is előmozdítják a diaszpórából történő hazatérést, így a vietnámi-francia vagy az algír-francia katonai konfliktus után sokan utaztak vissza szuilőföldjükre a Franciaországban élő algírok vagy vietnámiak közül.

A migránsok társadalmi összetartozása és a velük szembeni averzió vezetett New Yorkban az egykori bevándorlók által létrehozott ún. migrációs negyedek (kínai, olasz) kialakulásához, amelyek jellegzetes szegregációjuk és erösődő identitásuk révén napjainkban idegenforgalmi vonzerőként is szolgálnak. Útikönyvek tucatjai hívják fel arra a látogatók figyelmét, hogy az USA keleti partjának metropoliszában található „Chinatown” és „Little Italy” olyan miliővel rendelkezik, amely máig őrzi az egykori bevándorlók értékvilágát.

\section{A nyaralás és a vidéki életmód szerepe a migrációban}

A szociálgeográfia szempontjából az idegenforgalom az emberi lét egyik alapfunkciója, mert az üdülés, az idegenforgalom a szabadidős tevékenység egyik formája, lehetséges módja (Berényi 1997). Azzal, hogy a szabadidő-eltöltés társadalmi méretủvé vált, és az individuális és szervezett szabadidő-eltöltési formákra differenciált funkcionális rendszer épült, kialakult a társadalmi tevékenység csoportspecifikus jellege is, amely térben és időben felismerhetővé vált. A gazdasági fejlödéssel, s ezzel összefüggésben a munka termelékenységének növekedésével csökken a munkavégzésre fordított idő, és ezzel mind több társadalmi csoport számára nyilik meg a lehetőség, hogy az egyre növekvő szabadidejét megtervezze. A közlekedés fejlődése pedig lehetỏvé teszi a térbeli mobilitást, azt, hogy az ember a szabadidó egy részét a lakáson, illetve lakóhelyén kívül töltse.

Általános megállapítás, hogy a hétvégi pihenéssel összefüggő térbeli mobilitás a központtól mért $30 \mathrm{~km}$-es övezeten belül a legerősebb. A 30-100 km közötti távolságban már az üdülőházak dominálnak, amelyeket már nem minden hétvégén vesznek igénybe, míg az ennél nagyobb távolságra lévő üdülöházakat, üdülő lakásokat, apartmanokat már csak többnapos szabadidő vagy nyári és téli szabadságok idején 
Michalkó Gábor - Illés Sándor - Berényi István :

Adalékok a turizmus és a migráció kapcsolatának elméleti megközelítéséhez.

Tér és Társadalom 17. évf. 2003/4. 51-65. p.

használják. A szabadidős funkciók kialakulása egy település környezetében nemcsak a vendégek mint térhasználók mobilitását jelenti, hanem indikálhatja az őket kiszolgáló munkaerő mozgását is:

a) A hétvégi ház és üdülőővezetek kialakulásával kapcsolatos építkezés fellendíti a helyi építőipart (építőanyag-kereskedés, fuvarozás), megnő a szakemberek iránti igény (kőműves, ács, asztalos, burkoló, festő stb.), ami kedvező hatással van a helyi foglalkoztatásra, de előidézi az idénymunkások megjelenését is. A funkció kiépülésével pedig a kereskedö-szolgáltató funkció is növekedésnek indulhat (kiskereskedés, vendéglők).

b) Az üdüló jellegủ településeken és övezetekben, a térhasználók számától függően megjelennek a szakboltok: kertészeti, barkácsboltok, differenciált igényeket kielégítő üzletek és vendéglők, cukrászdák stb. Ha az üdülő és pihenőterület használata erősen szezonális (a Balaton-környék, Dél-Európa tengerpartjai vagy az Alpok síterepeinek többsége), akkor a településnek, illetve területnek jelentős időszakos munkaerő vonzása lehet. Az üdülö és pihenőterületeken megnőhet a kettős foglalkozású családok száma azzal, hogy a család rendszerint nố tagja szezonális vagy állandó munkát vállal az új ,iparban“.

c) A mobil szabadidős szállástípust preferálók térhasználata (camping caravaning) is növekvő szervezettséget mutat. Ez a jelentős vonzótényezővel rendelkezỏ települések vagy tájak esetében már szervezett fogadást feltételez, ami szintén foglalkoztatással jár, $\mathrm{s}$ lehet bizonyos munkaerő vonzása is.

A nemzetközi és a belföldi migráció a nyaralótulajdonosok tekintetében összemosódik. A nyaralás életstílusváltás, de azt a háztartásvezetés módosításának szándéka, vagy sajátos életkori szakaszok is motiválhatják. A letelepedésre alkalmas vidéki területek, vagy a külvárosi, eredeti funkcióját tekintve mezőgazdasági térségek rendszeresen céltábláivá válnak a migránsok vágyainak (Williams-Hall 2000). Az adott mezőgazdasági terulleten végbemenő funkcióváltás (parcellázást követỏ beépítés) a gazdaságosan megmúvelhető földterületek elfogyásához vezethet, de a migránsoknak már lakott vidéki területekre való beköltözése révén megindulhat a falusi dzsentrifikáció, ami akár az egykori dominánsan agrár-jellegú területek revitalizációjával is járhat.

Rudzitis (1991) kiemeli, hogy a migrációs döntésekben a nem gazdasági tényezőknek nő a szerepe. A leggyakoribb nem gazdasági tényező az időjárás, de a szolgáltatások mennyiségi, minőségi jellemzőinek is fontos szerepük van. A nem gazdasági tényezők megnehezítik a migrációs folyamatok modellezését, mivel szinte végtelen változatosságát adják a változóknak. A kutatók eddig kevés figyelmet szenteltek a nem nagyvárosi migrációnak, és nem volt a kérdésnek egységes elmélete sem. A decentralizációhoz (dezurbanizációhoz) a nagyvárosokból kiköltöző emberek mellett, a városi területekrỏl kiáramló vállalatok is hozzájárulnak. Ami egyedivé tesz egy helyet, azt nem a piac szolgáltatja, ugyanis a tiszta környezet, a szabad tér, a vadon, a jó iskolák és barátságos szomszédok nem tipikus piaci tényezők 
Michalkó Gábor - Illés Sándor - Berényi István :

Adalékok a turizmus és a migráció kapcsolatának elméleti megközelitéséhez.

Tér és Társadalom 17. évf. 2003/4. 51-65. p.

(legalábbis sokáig nem tekintették annak). A helyi politikának arra kell törekednie, hogy ezeknek az értékeknek a fejlesztésére, megvédésére helyezze a hangsúlyt.

\section{Távlatok}

A turizmus és migráció közötti kapcsolatok szerteágazó problematikájának jelen tanulmányban bemutatott - elsősorban a népességföldrajz, a turizmusföldrajz és a szociálgeográfia nemzetközi eredményeit alapul vevő - áttekintése a mobilitás két alapvető formájában érvényesülő szimbiózis gyökerének feltárását kívánja szolgálni. Egyrészt bizonyítást nyert, hogy léteznek azok a találkozási pontok, amelyek a turizmus és migráció viszonylatát tekintve a két jelenség értelmezésében elengedhetetlen szemléletváltásra ösztönöznek, másrészt megteremtette azokat az elméleti alapokat, amelyek mentén a vizsgálatok tovább folytatódhatnak. A kutatás során egyértelmúvé vált, hogy az egyes problématerületek elmélyültebb, primer forrásokra alapozódó feltárása nemcsak a kérdéseket tudományos igényességgel vizsgáló kutatói körök, hanem az államigazgatás szempontjából is kívánatos. A hiányzó információk jelentős mértékben elősegíthetik az európai uniós csatlakozásunk folyamatában kardinális kérdésnek tünő migráció, és az azzal igazoltan szoros kapcsolatot mutató turizmus terén a két folyamat befolyásolására irányuló döntéshozatalt.

\section{Jegyzetek}

\footnotetext{
'A tanulmány alapját képező kutatást az Egészségügyi, Szociális és Családügyi Minisztérium támogatta.

${ }^{2} \mathrm{http}: / / w w w . g e o g . n a u . e d u / i g u s t / m i g r a t i o n . h t m l$
}

\section{Irodalom}

Aitken, C.-Hall, M.C. (2000) Migrant and International Skills and their Relevance to the Tourism Industry: Fact and Fiction in the New Zealand Context. - Tourism Geographies. 1. 66-86. o.

Beer, B. (2000) Deutsch-philippinische Ehen: Tourismus, Familienferien und Verwandtenbesuche. Tourismus Journal. 4.3. 349-365. o.

Bell, M.-Ward, G. 2000: Comparing temporary mobility with permanent migration. - Tourism Geographies. 2.1.87-107. o.

Berényi I. (1997) A szociálgeográfía értelmezése. ELTE Eötvös Kiadó, Budapest.

Bianchi, R.V. (2000) Migrant tourist-workers: Exploring the 'contact zones' of post-industrial tourism. Current Issues in Tourism. 2. 107-137. o.

Cluzeau, O.C. (2001) Les diasporas, acteurs méconnus du tourisme. - Espaces. 5. 52-55. o.

Feng, K.-Page, S.J. (2000) An exploratory study of the tourism, migration-immigration nexus: travel experiences of Chinese residents in New Zealand. - Current Issues in Tourism. 3. 246-281. o.

Illés S. (2000) Belföldi vándormozgalom a XX. század utolsó évtizedeiben. Kutatási jelentések $63 . \mathrm{KSH}$ NKI, Budapest.

IIlés S. (2001) Külföldiek az Európai Unióból. - Statisztikai Szemle. 2. 162-177. o.

Massey, D.S. (2001) A nemzetközi migráció elméletei: áttekintés és értékelés. - Sik E (szerk.) A migráció szociológiája. Szociális és Családügyi Minisztérium, Budapest. 9-40. o.

Michalkó G. (2002) Turizmus: praxis vagy tudomány? (A turizmus tudománytani és felsőoktatási kérdései Magyarországon). - Aubert A. (szerk.) Kutatás a turizmusban - A turizmus aktuális kérdései Magyararszágon. PTE TTK Földrajzi Intézet, Pécs. 84-96. o.

Rédei M. (2001) Demográfia. ELTE Eötvös Kiadó, Budapest. 
Michalkó Gábor - Illés Sándor - Berényi István :

Adalékok a turizmus és a migráció kapcsolatának elméleti megközelítéséhez.

Tér és Társadalom 17. évf. 2003/4. 51-65. p.

Adalékok a turizmus és a ...

Rédei M. (2002) A külföldön tanuló magyar diảkok - a Magyarországon tanuló külföldi diákok. - Illés S.Lukács É. (szerk.) Migráció és statisztika. Kutatási jelentések. KSH Népességtudományi Kutatóintézet, Budapest. 113-133, o.

Rudzitis, G. (1991) Migration, sense of place, and nonmetropolitan vitality. - Urban Geography. 1. 80-88. o.

Szabó P. (2002) A gyermekek vándorlása - családegyesítés. - Illés S.-Lukács É. (szerk.) Migráció és statisztika. Kutatási jelentések. KSH Népességtudományi Kutatóintézet, Budapest. 97-111. o.

Timothy, D. (1995) International Boundaries: New Frontiers for Tourism Research. - Progress in Tourism and Hospitality Research. 1. 141-152. o.

Tóth P.P. (1997) Haza csak egy van? Menekủlök, bevándorlók, új állampolgárok Magyarországon, (1988-1994). Püski Kiadó, Budapest.

Truly, D. (2002) International retirement migration and tourism along the Lake Chapala Riviera: developing a matrix of retirement migration behaviour. - Tourism Geography. 3. 261-281. o.

Williams, M.A.-Hall, M.C. (2000) Tourism and Migration: New Relationships Between Production and Consumption. - Tourism Geographies. 1. 5-27. o.

Williams, M.A.-King, R.-Warnes, T-Patterson, G. (2000) Tourism and international retirement migration: new forms of an old relationship in southern Europe. - Tourism Geographies. 1. 28-49. o.

Zolberg, A. (2001) Újabb hullámok: migrációelmélet egy változó világban. - Sik E (szerk.) A migráció szociológiája. Szociális és Családuigyi Minisztérium, Budapest, 41-57. o.

\section{CONTRIBUTIONS TO THE THEORETICAL APPROACH OF THE RELATIONSHIP BETWEEN TOURISM AND MIGRATION}

\section{GÁBOR MICHALKÓ - SÁNDOR ILLÉS - ISTVÁN BERÉNYI}

Taking into account that an important feature of the migration process is travelling, certain phases of the phenomenon can be conceived as part of tourism, one of the most profitable and prospective industries of today. In spite of the obvious links between tourism and migration their academic research being pushed to the background might be attributed to the difficulties in an exact distinguishing between the two. Since the change of political regime (1990) there have been 25-30 million crossings of the border in the Republic of Hungary annually, which is a significant number with regard to the territorial extent and population of the country. Scant information is available if the entering foreigners should be considered tourists or migrants. As a consequence of the Trianon Peace Treaty, intentions of Hungarians living beyond the border to resettle to Hungary have never ceased and they are maintained by tourist visits to relatives and by living contacts. Moreover, Hungary presents an attraction to foreigners arriving from the European Union or overseas who have got acquainted with the attractions of Hungary and decided to settle here. Inland migration is motivated by pull of labour force, push by intense tourism turnover and by conversion of second homes to permanent housing. The study presents a theoretical overview of the problem followed by the analysis of the spatial aspects of tourism and migration including methodological connotations. 